\title{
Determinants of Concordance and Discordance Reporting of Contraceptive Use among Couples in Nigeria: Evidence from NDHS
}

\author{
Emmanuel Kolawole Odusina ${ }^{a}$, Luqman Bisiriyu ${ }^{b}$ and Akanni Akinyemi ${ }^{b}$

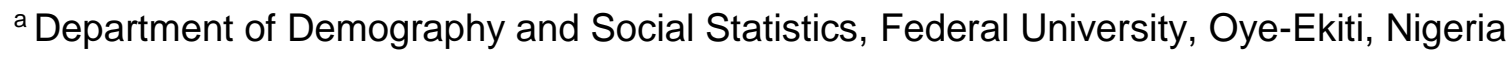 \\ ${ }^{\mathrm{b}}$ Department of Demography and Social Statistics, Obafemi Awolowo University, lle Ife, Nigeria
}

\begin{abstract}
Sexual behavior and contraceptive use dynamics within marital union presents a very complex and dyad interpretations. Among the complexities is the possibility of couples' sexual fidelity to each other, infidelity of either of the partners or both partners. Secondly, are the couples' approaches to other marital derivatives including fertility and contraceptive use. The analysis examined the determinants of concordance and discordance reporting of contraceptive use among couples in Nigeria with a view to understanding factors in concordance and discordance reporting of contraceptive use. The analysis utilized the 2008 NDHS couples recode dataset. The data were analyzed using Kappa Statistics and multinomial logistic regression. The results showed that age, education, wealth index, residence, fertility desire and fertility preference were significant factors predicting concordance reporting of contraceptive use $(P<0.05)$ while work status, wealth status and fertility preference were significant factors predicting discordance reporting of contraceptive use $(P<0.05)$. The analysis concluded that couples concordance reporting of contraceptive use is important in fertility control and in addressing the scourge of HIV/AIDS and other STIs in Nigeria.
\end{abstract}

Keywords Contraception, Fertility, Couples, STIs, HIV/AIDS

\section{Résumé}

La nécessité de comprendre le comportement sexuel et l'utilisation du contraceptif au sein des couples congugal est très nécessaire pour le contrôle de la fertilité et de la lutte contre les IST et le VIH. Le comportement sexuel et l'utilisation de la contraception des couples fournira des informations qui vous aidera dans la lutte contre la fertilité et la menace des IST et du VIH / SIDA. L'accord par les couples sur l'utilisage de la contraception ou non est un facteur important pour la fertilité. La réduction des incidents de IST et le VIH pour augmenter le bien-être de la famille. Par conséquent, cette étude a examiné les déterminants de la concordance et la discordance des rapports d'utilisation des contraceptifs chez les couples au Nigeria en vue de la comprehension de facteurs en concordance et discordance d'utilisation des contraceptifs. L'analyse a utilisé le jeu de données des enregistrés couples en 2008. Les données ont été analysées à l'aide de Statistique Kappa et la régression logistique multinomiale. Les résultats ont montré que l'âge, l'éducation, l'indice de richesse, la résidence, le désir de la fécondité et la préférence de la fertilité ont été des facteurs importants pour la prediction de la concordance de rapport de de l'utilisation de la contraception $(P<0,05)$, tandis que le statut de travail, l'état de la richesse et de la préférence de la fertilité ont été des facteurs importants prédisant les rapports de discordance d'utilisation des contraceptifs $(P<0,05)$. L'analyse a conclu que les rapports de la concordance des couples pour l'utilisation des contraceptifs est important dans le contrôle de la fétilité et de la lutte contre le fléau du VIH / SIDA et des autres IST au Nigeria.

Mots-clés: Contraception, fertilité, Couples, IST, VIH / SIDA

\section{Introduction}

The contraceptive prevalence rate still remains relatively low in Nigeria as only 9.8 percent of married women utilized family planning and an estimated 16 percent with unmet needs for family planning (NPC and ICF Macro, 2009). Family planning and fertility discourses differ among couples in marital union compared with unmarried individuals. Couples centered analysis of contraceptive use is very limited in Nigeria and the understandings of the factors 
influencing its use within marital union are complex. This makes information on contraceptive use dynamics in marital union very scanty. For instance, socio-cultural issues around marital fidelity vary for male and female in many Nigeria cultures. Whereas females are labeled for extra-marital affairs, such is generally relaxed when the male folk is involved (Nnodum, 2004 and Smith, 2010). Extra-marital affairs constitute a major sustaining factor for the upsurge of HIV/AIDs and other sexually transmitted diseases. Particularly, among couples in monogamous relationships, extra-marital affairs constitute a major high risk of contracting STls. The need for couplecenter in developing country had been raised for over a decade (Dodoo, 1993; Kritz, 1999 and Thomson and Hoem, 1998), yet, very few researches have been able to explore this in connection to other sexual and reproductive health issues.

Marriage provides some form of coverage for fertility, irrespective of its wantedness or not. Evidence has confirmed that many children even within marriage are not desired or are products of unwanted pregnancies (Oyediran and Abanihe, 2002; Adewuyi and Ogunjuyigbe, 2003; Akinyemi and Abanihe, 2014). Ability to regulate fertility among couples requires deliberate actions and behavior including agreement on the desired number of child. A major pathway in achieving this is through agreement on the use of contraceptive. However, there are major issues within family arrangements and structures that affect sexuality and family planning. Some of these relate to issues bothering on marital fidelity and communication.

Evidences from previous studies have clearly demonstrated that spousal communication increases the likelihood of the uptake of family planning and fertility regulation among couples (Oyediran and Isiugo-Abanihe, 2002; Bankole, 1995; Bawah, 1999; Odimegwu 1999). Also, Diro and Afework (2013) in their study on family planning attitudes and intentions found that collective information from husbands and wives on family planning was a key determinant of contraceptive use. In the study by Irani et al, (20/4), they found that couples who reported spousal communication on family planning in the past six months were more likely to use contraceptives compared to those who reported no spousal communication. With some of the evidences, the importance of relationship-level characteristics on contraceptive use among couples has well been established. Lack of or ineffective spousal communication can hinder effective contraceptive use (Kamran, Arif and Vassos, 20l I).

However, many of these studies have either used small sample data or make inferences on couples' decision making with responses from either of the partners. This analysis main contribution is on a nationally representative data in which both the views of both spouses were collected and matched. The central question of the analysis is to examine if couples' characteristics (age, work status, wealth status, education, etc.) are influential in contraceptive use. What are the characteristics of couples that enhance or discourage contraceptive use? Therefore, this study explores the determinants of concordance and discordance reporting of contraceptive use among couples in Nigeria.

\section{Methods}

The Nigeria Demographic and Health Survey (NDHS) dataset of 2008 was used. The dataset was used because it is national and representative. The target population was matched couples of the Nigeria DHS 2008 recode data set. There were 8,73I matched couples. Men and women (couples) data were analyzed and the DHS definition of a couple was adopted: a man and woman who are legally married or living together in a consensual union. Polygamous couples were excluded from the analysis because questions on sexual activity of husbands were not specific to a particular partner or wife. The data of 4040 eligible couples were considered for data analyses. Kappa Statistic was employed to evaluate the level of agreement between couples' characteristics and contraceptive use. This was to ascertain and assess whether the concordance in reports was due to chance alone. Multinomial logistic regression technique was used to establish the relationship between contraceptive use and couples' characteristics.

\section{Dependent Variable}

Dependent variable was derived from the reports of men and women (matched couples) on current use of contraceptive. All the categories of responses by men and women were collapsed and (couples) were further classified into $I=$ both were using, $2=$ both were not using and $3=$ either was using.

\section{Independent Variables}

The key independent variables employed in the study were age, level of education, work status, wealth status, residence, spousal communication/decision making, fertility desire and fertility preference. Age was group into three: $I=$ same age, $2=$ husbands 3 years older and $3=$ wives 3 years older. Years spent in schools (education) by couples were collapsed and coded I= same education, $2=$ husbands more educated and $3=$ wives more educated. Residence as reported by DHS needed no further classification, urban was 
coded one while rural was coded two. Occupations (work status) of couples were coded I if both were working while other categories were coded 2 . Wealth status as reported by DHS was classified into five categories; however, this study reduced the categories to three. The first and the second group (Poorest and Poorer) were classified as poor; the third group (middle) remained as it was while the fourth and the fifth group (richer and richest) were classified as rich. Variable on decision about wives/husbands income was used as a proxy for spousal communication/decision making and was classified into $\mathrm{I}=$ both take decision together and 2 $=$ others. Fertility desire as a variable was classified into $I=$ equal desire, 2 = husbands desire more and $3=$ wives desire more while fertility preference was categorized into I = both want another, 2 = both want no more and $3=$ others. Collinearity check did not reveal high degree of collinearity between education and wealth index, education and work status and wealth index and work status.

\section{Findings}

Demographic and Socio-economic Characteristics of Couples

Table I showed the demographic and socioeconomic characteristics of couples. The table revealed that 17.I percent of couples had the same age (that is, difference of less than 3 years between wife and husband), while 0.77 percent of women indicated they were three years plus older than their husbands. Husbands (82.I percent) were older than their wives in most of the eligible couples. In all, 43.35 percent of couples had the same level of education, 39.36 percent of couples reported that husbands were more educated while 17.29 percent indicated wives were more educated. Majority of couples, 63.23 percent, lived in rural areas as against 36.77 percent who lived in urban areas.

Couples (husbands and wives) who indicated that they worked in the last twelve months preceding the survey were 66.35 percent of the study population. Wealth index as a variable was a function of component analysis of household's possessions and the related socio-economic variables. Overall, 39.2I percent of couples were from poor households, 16.73 percent were in the middle range households while 44.06 percent were from rich households. For the purpose of this study, the number of children ever born by wives was used. This tends to be more reliable because men may include other children born out of extramarital affairs, foster children, etc. Children ever born by women were grouped into two, such as 'zero to four children' and 'five and more children'. In all, the survey population recorded 65.39 percent of its children ever born to couples who claimed to have less than five children, which was, 0-4 children. While couples with 5 and more children ever born accounted for 34.61 percent of the study population. The information on number of living children was grouped into two different categories such as: ' 0 - 4 children' and ' 5 and more children'. In all, 74.94 percent of couples had zero to 4 children while 25.06 percent had 5 and more children. The responses on contraceptive use showed that 69.78 percent of couples were not current users of contraceptives, 20.89 percent indicated either of the couples was using contraceptives and only 9.34 percent of the couples indicated that both were using contraceptives. 
Table I: Percentage Distribution of Couples by Selected Demographic and Socio-economic Characteristics

\section{Characteristics}

Age $(\mathrm{N}=4040)$

Same age

Wife 3 years plus older

Husband 3 years plus older

Education $(\mathrm{N}=4033)$

Same education

Husband has more education

Wife has more educational

Residence $(\mathrm{N}=4040)$

Urban

Rural

Work Status $(\mathrm{N}=4040)$

Both are working

Others

Wealth Index $(\mathrm{N}=4040)$

Poor

Middle

Rich

Spousal Communication/decision Making $(\mathrm{N}=4040)$

Both partners

Others

Fertility Desire $(\mathrm{N}=4040)$

Equal desire

Husbands desire more

Wives desire more

Fertility Preference $(\mathrm{N}=4040)$

Both want another

Both want no more

Others

CEB $(\mathrm{N}=4040)$

$0-4$

5 and more

Number of Living Children ( $N=4040)$

$0-4$

5 and more

Contraceptive Use $(\mathrm{N}=4040)$

Both are not using

Both are using

Either is using

\section{Percent}

17.11

0.77

82.12

43.35

39.36

17.29

36.77

66.35

33.65

39.21

16.73

44.06

12.44

87.56

61.79

32.73

5.48

57.95

10.87

31.19

65.39

34.61

74.94

25.06

69.78

9.34

20.89

No response category excluded. Source: Author's Work, 2015. (Data from 2008 NDHS)

\section{Selected Socio-demographic Characteristics by} Contraceptive Use with Kappa Statistics

The relationships between selected sociodemographic factors and the use of contraceptive were examined by the use of Kappa test. It was employed to evaluate the level of agreement between couples' characteristics and contraceptive use, to ascertain and assess whether the concordance in reports was due to chance. As shown in Table 2, the overall agreement between age and contraceptive use was 25.65 percent, education and contraceptive use was 43.07 percent (significant at $\mathrm{P}<0.00 \mathrm{I}$ ), work status and contraceptive use was 44.63 percent, wealth index and contraceptive use was 52.53 percent (Significant at $\mathrm{P}<0.00 \mathrm{I}$ ), residence and contraceptive use was 21.59 percent, spousal communication/decision making and contraceptive use was $13.35 \%$, fertility desire and contraceptive use was 40.04 percent, fertility preference and contraceptive use was $55.6 \mathrm{I}$ percent (Significant at $\mathrm{P}<0.00 \mathrm{I})$. The values of Kappa for the selected 
independent variables and contraceptive use indicated poor agreement.

Moreover, contraceptive use and characteristics of couples such as age, education, work status, type of residence, wealth status, fertility desire, children ever born, number of living children, fertility preference and type of residence were examined (Table 2). Couples with same age reported that 60.77 percent were not current users of contraceptive but II.72 percent were current users of contraceptive while 27.5 I percent indicated either was currently using contraceptive. Couples who reported that wives were three or more years older than the husbands claimed that 80.69 percent were not currently using contraceptive while 19.31 percent reported either of them was currently using contraceptive. Couples who reported husbands were three years older than their wives reported that 71.55 percent were not currently using contraceptive methods, 08.93 percent were both currently using contraceptive while 19.52 percent indicated either of them was currently using contraceptive methods. Overall, couples who reported same age had the highest proportion (II.72\%) of those who were using contraceptive. The chi-square test showed significant association between age and current use of contraceptive $(P<0.00 \mathrm{I})$.

Reports on couples with the same education showed that $\mathbf{7 7 . 5}$ percent were not currently using contraceptive, 06.12 percent reported both were current users of contraceptive and 16.37 percent reported either was using contraceptive. Reports on couples where husbands were more educated showed 76.73 percent were not currently using contraceptive methods, 10.12 percent were both current users of contraceptive and 16.37 percent indicated either was using contraceptive. Analysis of couples where wives were more educated revealed 57.32 percent were not current users of contraceptive methods, 15.69 percent were current users while 26.98 percent claimed either was currently using contraceptive methods. The chisquare test revealed significant relationship between educational attainment and current contraceptive use by couples $(\mathrm{P}<0.00 \mathrm{I})$.

Work status may discourage or stimulate the use of contraceptive. The desire to increase standard of living may prompt couples to reduce fertility through the use of contraceptive methods. Table 2 presents the bivariate relationship between work status and current contraceptive use by couples. Couples who were both working gave the following information: 64.95 percent were not currently using, 10.98 percent were both currently using and 24.07 percent indicated either was currently using contraceptive methods. Higher percentage of contraceptive use was observed among couples who were working. The result of chi-square test showed significant relationship between work status and current use of contraceptive methods $(\mathrm{P}<0.00 \mathrm{I})$. Literature has indicated more use of contraceptive methods in urban areas compare to rural areas. The finding as a result of cross tabulation between type of residence and current contraceptive use by couples as presented in Table 2 buttressed this claim. Though the percentage of couples who were both currently using contraceptive methods was very low in both urban areas (17.39 percent) and rural areas (04.65 percent) but it was higher in urban areas compared to rural areas. Those who were not currently using contraceptive methods were 54.33 percent and 78.76 percent in both urban areas and rural areas respectively. Bivariate analysis by chi-square test revealed significant relationship between type of residence and current use of contraceptive methods $(\mathrm{P}<0.00 \mathrm{I})$.

The table revealed positive relationship between wealth status and current use of contraceptive methods. The table also revealed that among the poor couples, 89.61 percent was not currently using contraceptive methods, 01.57 percent were both currently using contraceptive methods and 08.82 percent claimed either of the couples was currently using contraceptive methods. The analysis of couples in the middle level indicated that $\mathbf{7 4 . 4 2}$ percent were both currently not using contraceptive methods, 05. 15 percent were current users while 20.44 percent claimed either was using contraceptive methods. Among the rich couples, 50.37 percent were not using, 17.83 percent were both using and 20.89 indicated either was using. Bivariate analysis produced significant relationship between wealth status and current contraceptive use by couples $(\mathrm{P}<0.00 \mathrm{I})$. Analysis of fertility desire by current use of contraceptive by couples revealed husbands desired more (83.27 percent) among couples who claimed they were not using contraception. Where couples indicated both were using contraception, wives desire was more pronounced (29.56 percent) while where either was using contraceptive, equal desire among couples was more prominent (32.86 percent). Further analysis with the use of chi-square test revealed significant relationship between fertility desire and current contraceptive use by couples $(\mathrm{P}<0.00 \mathrm{I})$.

Couples who responded to having less than five children (CEB) gave the following information as regard the use of contraceptive: 68.91 percent of them claimed both couples were not current users of contraceptive methods, 9.88 percent claimed both were current users of contraceptive methods while 21.21 percent indicated either was current users of 
contraceptive methods. In the category of couples who claimed to have five and more children ever born, 7l.4I percent indicated they were current users, 8.3I percent claimed both were current users while 20.28 percent reported either was current users of contraceptive methods. Analysis of the variables by the use of chi-square test showed no significant relationship between total children ever born and the use of contraceptive methods $(P=0.27)$. Moreover, number of living children was also considered in the analysis. Among couples who had zero to four children, 70.14 percent were not currently using contraceptives methods, 09.5 I percent reported both were using contraceptive methods and 20.34 percent responded that either of the couples was using contraceptive methods. Among couples who indicated they had five and more children, 68.68 percent were not currently using contraceptive methods, $08.8 \mathrm{I}$ percent claimed both were using contraceptive while $22.5 \mathrm{I}$ percent claimed either was using contraceptive methods. The result of the chi-square test showed significant relationship between number of living children and current use of contraceptive methods by couples.

The relationship between fertility preference and current use of contraceptive was examined as shown in Table 2. Overall, 75.55 percent of couples who indicated they both wanted more children were not currently using contraceptive and 43.63 percent of those who indicated both wanted no more children were not currently using contraceptive. Among couples who were using contraceptive, 07.26 percent wanted more children and 21.08 percent claimed both wanted no more children. Further test by the use of chi-square revealed a significant relationship between fertility preference and current contraceptive use by couples $(\mathrm{P}<0.00 \mathrm{I})$. The use of contraceptives was low among couples who did not take joint decision (7I.49 percent). The current use of contraceptives (though low generally) was higher among couples who were communicating/taking joint decisions. The chi-square test showed significant relationship between spousal communication/decision making and current contraceptive use $(\mathrm{P}<0.00 \mathrm{I})$

Table 2: Selected Socio-demographic Characteristics by Contraceptive Use with Kappa Statistics

\begin{tabular}{|c|c|c|c|c|}
\hline \multirow{3}{*}{ Couples' Characteristics } & \multicolumn{3}{|c|}{ Dependent Variable } & \multirow{3}{*}{$\begin{array}{c}\text { Couple } \\
\text { Agreement } \\
\text { (Kappa) }\end{array}$} \\
\hline & \multicolumn{3}{|c|}{ Contraceptive Use } & \\
\hline & $\begin{array}{l}\text { Both were } \\
\text { not using }\end{array}$ & $\begin{array}{l}\text { Both were } \\
\text { using }\end{array}$ & $\begin{array}{l}\text { Either was } \\
\text { using }\end{array}$ & \\
\hline \multicolumn{5}{|l|}{ Difference in Age } \\
\hline Same Age & $60.77 \%$ & $11.72 \%$ & $27.51 \%$ & \multirow{3}{*}{$\begin{array}{l}25.65 \% \\
(-0.03)\end{array}$} \\
\hline Wives more than 3 years older & $80.69 \%$ & $0.0 \%$ & $19.31 \%$ & \\
\hline Husbands more than 3 years older & $71.55 \%$ & $08.93 \%$ & $19.52 \%$ & \\
\hline \multicolumn{5}{|l|}{ Educational Attainment } \\
\hline Same education & $77.51 \%$ & $06.12 \%$ & $16.37 \%$ & \multirow{3}{*}{$\begin{array}{l}43.07 \% \\
(0.07)^{* * * *}\end{array}$} \\
\hline Husbands more educated & $66.73 \%$ & $10.12 \%$ & $23.15 \%$ & \\
\hline Wives more educated & $57.32 \%$ & $15.69 \%$ & $26.98 \%$ & \\
\hline \multicolumn{5}{|l|}{ Work Status } \\
\hline Both are working & $64.95 \%$ & $10.98 \%$ & $24.07 \%$ & \multirow{2}{*}{$\begin{array}{l}44.63 \% \\
(-0.06) \\
\end{array}$} \\
\hline Others & $79.30 \%$ & $06.1 \%$ & $14.6 \%$ & \\
\hline \multicolumn{5}{|l|}{ Wealth Index } \\
\hline Poor & $89.61 \%$ & $01.57 \%$ & $08.82 \%$ & \multirow{3}{*}{$\begin{array}{l}52.53 \% \\
(0.19)^{* * *}\end{array}$} \\
\hline Middle & $74.42 \%$ & $05.15 \%$ & $20.44 \%$ & \\
\hline Rich & $50.37 \%$ & $17.83 \%$ & $31.8 \%$ & \\
\hline \multicolumn{5}{|l|}{ Type of Residence } \\
\hline Urban & $54.33 \%$ & $17.39 \%$ & $28.28 \%$ & \multirow{2}{*}{$\begin{array}{l}21.59 \% \\
(-0.10)\end{array}$} \\
\hline Rural & $78.76 \%$ & $04.65 \%$ & $16.59 \%$ & \\
\hline \multicolumn{5}{|l|}{$\begin{array}{l}\text { Spousal Communication/Decision } \\
\text { Making }\end{array}$} \\
\hline Both Partners & $57.69 \%$ & $12.37 \%$ & $29.94 \%$ & \multirow{2}{*}{$\begin{array}{l}13.35 \% \\
(-0.02)\end{array}$} \\
\hline Others & $71.49 \%$ & $08.91 \%$ & $19.6 \%$ & \\
\hline Fertility Desire & & & & \\
\hline
\end{tabular}




\begin{tabular}{|l|l|l|l|l|}
\hline \multirow{2}{*}{ Couples' Characteristics } & \multicolumn{3}{|c|}{ Dependent Variable } & \multirow{2}{*}{$\begin{array}{c}\text { Couple } \\
\text { Agreement } \\
\text { (Kappa) }\end{array}$} \\
\cline { 2 - 4 } & \multicolumn{3}{|c|}{ Contraceptive Use } \\
\cline { 2 - 4 } & $\begin{array}{c}\text { Both were } \\
\text { not using }\end{array}$ & $\begin{array}{c}\text { Both were } \\
\text { using }\end{array}$ & $\begin{array}{c}\text { Either was } \\
\text { using }\end{array}$ & \\
\hline Equal Desire & $58.42 \%$ & $13.55 \%$ & $28.02 \%$ & $40.04 \%$ \\
\hline Husbands desired more & $83.27 \%$ & $03.78 \%$ & $12.95 \%$ & $(-0.12)$ \\
\hline Wives desired more & $46.64 \%$ & $29.56 \%$ & $23.8 \%$ & \\
\hline Fertility Preference & & & & \\
\hline Both want another & $75.55 \%$ & $07.26 \%$ & $17.19 \%$ & $55.61 \%$ \\
\hline Both want no more & $43.63 \%$ & $21.08 \%$ & $35.3 \%$ & $(0.10)^{* * *}$ \\
\hline Others & $68.16 \%$ & $09.11 \%$ & $22.73 \%$ & \\
\hline Source & & \\
\hline
\end{tabular}

Source: Author's Work, 20I5. (Data from 2008 NDHS) Significant at $* * * \mathrm{P}<0.00 \mathrm{I},{ }^{*} * \mathrm{P}<0.00 \mathrm{I} \quad * \mathrm{P}<0.05$. Note: Data for cross-tabulation (but not for kappa values) were weighted

Estimates of Odd Ratios Predicting Concordance Reporting of Contraceptive Use

Multinomial logistic regression model (Table 3) was simulated to see how selected socio-demographic characteristics of respondents influence concordance reporting of contraceptive use. Comparison one compared the probability of couples were using contraceptive versus couples were not using contraceptive and comparison two compared the probability of either of the couples was using versus both were not using contraceptive.

In the model, eight variables were loaded. For comparison one, (probability both were using (concordance)) six variables (age, education, wealth index, residence, fertility desire and fertility preference) were significant in predicting concordance reporting of contraceptive use whereas only three variables (work status, wealth index and fertility preference) also significantly predicted the odds of either (discordance) was using contraceptive (comparison two). Comparing significant predictors of contraceptive use across comparisons one and two revealed that two variables, wealth index and fertility preference were both significant in predicting likelihood of both were using (concordance) and either was using (discordance) contraceptive among couples.

Table 3: Odds of Using Method of Contraception by Some Selected Socio-demographic Characteristics

\section{Variables}

Both were using

Either was using

$\begin{array}{lllll}\text { Odd Ratio } 95 \% & \text { C. I. } & \text { Odd Ratio } 95 \% & \text { C. I. }\end{array}$

Difference in Age

\section{Same Age}

Wives more than 3 years older

Husbands more than 3 years older

Educational Attainment

Same education

Husbands more educated

Wives more educated

Work Status

Both are working

Others

Wealth Index

Poor

Middle

Rich

Type of Residence

Urban

Rural
$\mathrm{RC}$

$0.01^{* * * *}$

$0.70 *$

$0.01, \quad 0.02$

$0.49, \quad 0.99$

$\mathrm{RC}$

I.48*

I.73**

I.06, $\quad 2.07$

I.18, 2.55

$\mathrm{RC}$

I. 44

$\mathrm{RC}$

$2.5 I^{* * *}$

$7.12 * * *$

I.34,

4.70

3.96 ,

12.79

$\mathrm{RC}$

$0.52 * * *$

0.35

0.77

0.96

$\mathrm{RC}$

0.46

$0.6 I^{* * * *}$

0.14

1.56

$0.46, \quad 0.82$

RC

1.13

0.87 ,

1.47

I. 10

0.81 ,

I.5 I

RC

I. $44 * *$

I.10,

1.88

$\mathrm{RC}$

2.37*** $\quad 1.65, \quad 3.40$

$4.8 I^{* * * *}$

3.40 ,

6.82

RC

0.72 , 


\begin{tabular}{|c|c|c|c|c|c|c|}
\hline \multirow{3}{*}{ Variables } & \multirow{2}{*}{\multicolumn{3}{|c|}{ Both were using }} & \multirow{2}{*}{\multicolumn{2}{|c|}{ Either was using }} & \multirow[b]{3}{*}{ C. I. } \\
\hline & & & & & & \\
\hline & Odd Ratio & $95 \%$ & C. I. & Odd Ratio & $95 \%$ & \\
\hline \multicolumn{7}{|l|}{ Spousal Communication/ } \\
\hline \multicolumn{7}{|l|}{ Decision Making } \\
\hline Both Partners & $\mathrm{RC}$ & & & $\mathrm{RC}$ & & \\
\hline Others & 0.87 & 0.55 & 1.37 & 0.80 & 0.58 & I.II \\
\hline \multicolumn{7}{|l|}{ Fertility Desire } \\
\hline Equal desire & $\mathrm{RC}$ & & & $\mathrm{RC}$ & & \\
\hline Husbands desire more & $0.35^{* * * *}$ & 0.21 & 0.59 & $0.52 * * *$ & 0.39 & 0.69 \\
\hline Wives desire more & $2.38^{* * *}$ & $\mathrm{I} .35$ & 4.17 & 0.93 & 0.55 & 1.56 \\
\hline \multicolumn{7}{|l|}{ Fertility Preference } \\
\hline Both want another & $\mathrm{RC}$ & & & $\mathrm{RC}$ & & \\
\hline Both want no more children & $3.12 * * *$ & 2.11 & 4.62 & $2.65^{* * * *}$ & $\mathrm{I} .87$ & 3.74 \\
\hline Others & I.59*** & 1.12 & 2.25 & $1.66 * * *$ & 1.30 & 2.13 \\
\hline
\end{tabular}

Source: Author's Work, 20I5. (Data from $2008 \mathrm{NDHS}$ ) Significant at $* * * \mathrm{P}<0.00 \mathrm{I} * * \mathrm{P}<0.0 \mathrm{I} * \mathrm{P}<0.05$. RC - Reference Category

\section{Discussion}

Level of education, residence (Tawiah, 1997; Adhikari, 2010; NPC and ICF Macro, 2014), wealth status, age, fertility desire and preference of couples are determinants of concordance reporting of contraceptive use among couples in Nigeria. The discordance reporting of the use of contraceptive among couples is associated with work status, wealth status and fertility preference. As the couples increase in wealth, so also was the concordance reporting of the use of contraceptive by them. The concordance reporting of the use of contraceptive by couples was high when couples indicated that they wanted no more children and other reasons rather than when both couples agreed to have another child. The study showed that couples in urban areas were more likely to report concordance use of contraceptive. All the above explanations suggest the importance of education, wealth status, residence and fertility preference in concordance reporting of contraceptive use while discordance reporting of the use of contraceptive was associated with work status, increase in wealth and couples who wanted no more children. In other word, it can be asserted from this study that age, wealth status, fertility desire and preference are influential factors in concordance reporting of contraceptive use by couples while factors in discordance reporting of contraceptive use by couples are work status, wealth status and fertility preference.

\section{Conclusion}

The study found evidence of six (6) and three (3) significant factors predicting concordance and discordance reporting of contraceptive use among couples respectively. The observed concordance in contraceptive behaviour can be explained within the context of variation in age, education, wealth status, residence, fertility desire and preference while the observed discordance can be explained within the context of variation in work status, wealth status and fertility preference. Therefore, a programme of intervention targeting concordance use of contraceptive among couples may achieve its objectives if age, education, wealth status, residence, fertility desire and preference of couples are taking into consideration.

\section{References}

Adewuyi, A. and Ogunjuyigbe, P. (2003). The Role of Men in Family Planning: An Examination of Men's Knowledge and Attitudes to Contraceptive Use Among the Yorubas. African Population Studies, Vol. 18, No. I, April, pp. 35-49.

Adhikari, R. (2010). Demographic, Socio-economic, and Cultural Factors AffectingFertility Differentials in Nepal. The BioMed Central. The Open Access Publisher, VIO,

Akinyemi, A. I. and Isuigo-Abanihe, U. C. (20I4). Demographic Dynamics and Development in Nigeria: Issues and Perspectives. African Population Studies, Vol. 27, No. 2, March, pp.239-248.

Bankole, A. (1995). Desired Fertility and Fertility Behaviour among Yoruba of Nigeria: A Study of Couple Preferences and Subsequent Fertility," Population Studies 49: 317-328.

Bawah, A. A. (1999). Spousal Communication and Family Planning Behavior in Navrongo: a Longitudinal Assessment. Studies in Family Planning 33:185-94.

Diro, C. W. and Afework, M. F. (2013). Agreement and Concordance between Married Couples Regarding Family Planing Utilization and Fertility 
Intention in Dukem, Ethiopia. BMC Public Health, 13:903.

Dodoo, F. N. (1993). A Couple Analysis of Microlevel Supply/Demand Factors in Fertility Regulation. Population Research and Policy Review, I2(2): 93-10।

Irani, L., Speizer, I. S., and Fotso, J. (20/4). Relationship Characteristics and Contraceptive Use among Couples in Urban Kenya. International Perspectives on Sexual and Reproductive Health, 40(I): II-20.

Kamran, I., Arif, M. S. and Vassos, K. (20II). Concordance and Discordance of Couples Living in a Rural Pakistani Village: Perspectives on Contraception and Abortion - a Qualitative Study. International Journal for Research, Policy and Practice, 6(I):538-55I.

Kritz, M. M. (1999). Husband and Wife Agreement, Contraceptive Use and Ethnicity in Nigeria. New York: Population and Development Program, Working Paper Series, Department of Rural Sociology, Cornell University.

National Population Commission (NPC) [Nigeria] and ORC Macro. (2004). Nigeria

Demographic and Health Survey 2003. Calverton, Maryland: National Population Commission and ORC Macro.

National Population Commission (NPC) [Nigeria] and ICF Macro. 2009. Nigeria

Demographic and Health Survey 2008. Abuja, Nigeria: National Population Commission and ICF Macro.

National Population Commission (NPC) [Nigeria] and ICF Macro. 20I4. Nigeria

Demographic and Health Survey 2013 (Preliminary Report). Abuja, Nigeria: National Population Commission and ICF Macro.

Nnodum, B. I (2004).Incidence and causes of marital infidelity as perceived by secondary school teachers in Orlu Educational Zone of Imo State.The Nigerian Journal of Guidance and Counselling Vol. 9(I): 270-285
Odimegwu, C. (1999). Family Planning

Attitudes and Use in Nigeria: A Factor Analysis. International Family Planning Perspective. 25(2):8691.

Oyediran, K. A. and Isiugo-Abanihe, U. C. (2002) Husband-Wife Communication and Couple's Fertility Desires among the Yoruba of Nigeria. African Population Studies, Vol. 17, No. 2, pp. 6I-80

Tawiah, E. O. (1997). Factors Affecting Contraceptive Use in Ghana, Journal of Biosocial Science Vol. 29, I4I-I49, Cambridge University Press.

Thomson, E. and Hoem, J. M. (1998). Couple Childbearing Plans and Births in Sweden. Demography, 35 (3): 315-322.

Tuloro, T., Deressa, W., Ali, A. and Davey, G. (2006). The Role of Men in Contraceptive Use and Fertility Preference in Hossana Town, Southern Ethiopia. Ethiop. J. Health Dev. 20(3): I52-159.

Tumlinson, K., Speizer, I. S., Davis, J. T., Fotso, J. C., Kuria, P. and Archer, L. (20I4). Parner Communication, Discordant Fertility Goals, and Contraceptive Use in Urban Kenya.African Journal of Reproductive Health, 17(3):79-90 African Journal of Reproductive Health, I7(3):79-90.

Westoff, C. F. and Ochoa, L. H. (199I). Unmet Need and the Demand for Family

Planning, DHS Comparative Studies, Columbia, MD, USA: Institute for Resource Development/Macro International, 199I, No. 5,

Wolff, B., Blanc, A. K., and Ssekamatte-Ssebuliba, J. (2000). The Role of Couple Negotiation in Unmet Need for Contraception and the Decision to Stop Childbearing in Uganda. Studies in Family Planning $3 I$ (2) June 